\section{Animal Work}

Variations in pupillary size were observed in experiments on ten tracheotomised rabbits: in four animals the cannula was clamped abruptly and completely until the rabbit died; in two animals the cannula was compressed partially, gradually increasing obstruction until the respiration ceased; and in four animals several shortlasting total compressions were alternated with full release of the clamp, until after' a certain time total compression was maintained until cessation of breathing efforts. The results are seen in table III.

TABLE III-PUPIL SIZES IN RABBITS BEFORE AND AFTER CIRCULATORY ARREST

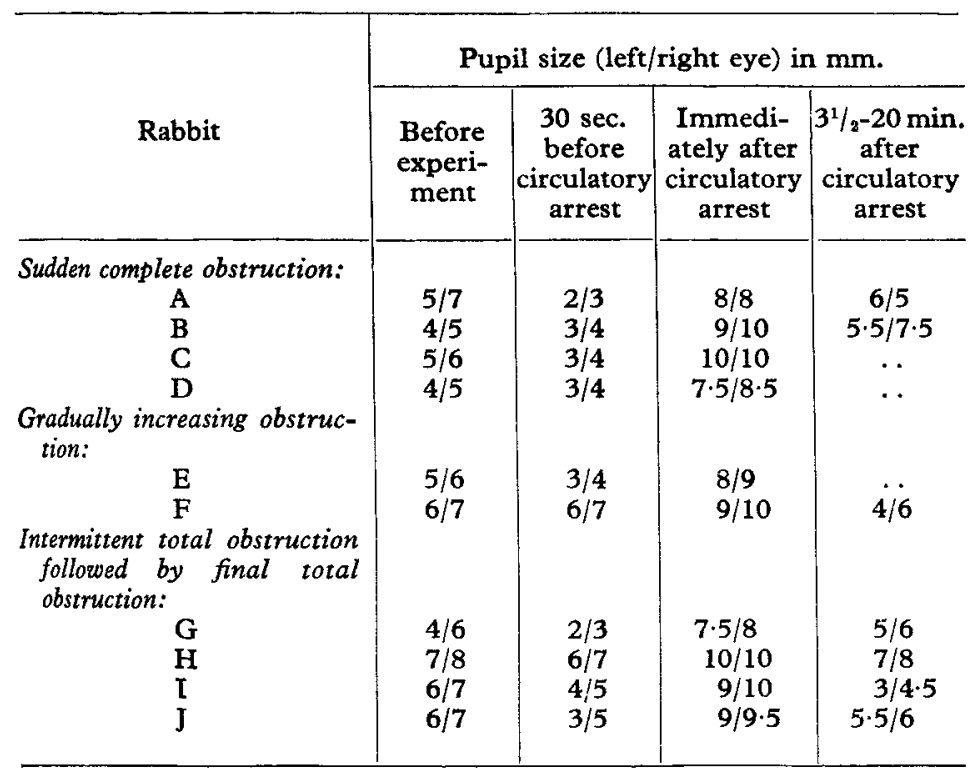

In no animal was dilatation of the pupils recorded at any time before death. On the contrary, pupillary size decreased after complete obstruction, this being very pronounced during the last 30 seconds of straining and vigorous respiratory effort. In experiments with intermittent compression or gradually augmented compression of the canula the diameter of the pupils remained unchanged for as long as 54 minutes and always until just after death.

In those animals who had intermittent compression of the breathing tube, no change in the pupillary size was recorded during periods of $1 \frac{1}{2}-2$ minutes of complete obstruction, nor after full release of the clamp. When total obstruction exceeded 2 minutes pupillary diameter rapidly decreased. If at that moment the clamp was released, the rabbits survived and the pupils quickly dilated to a diameter up to some $2 \mathrm{~mm}$. larger than that before the experiment, but after this they regained their original size. When the clamp was not released while the pupils were constricted, which lasted some 30 seconds, death supervened, this being accompanied by increase in the pupillary diameter. After death the pupils again started to get smaller after a few minutes.

\section{Discussion}

Patients in respiratory failure who had clinical signs of severe hypoxia and a $\mathrm{P}_{\mathrm{a}} \mathrm{O}_{2}$ as low as $34 \mathrm{~mm} . \mathrm{Hg}$, did not display any increase in pupillary diameter. An increase in pupillary size cannot, apparently, be used as a reliable sign of anoxia, even when the anoxia is severe.

Under thiopentone anæsthesia a patient's pupils vary with the depth of anæsthesia, but, as in unanæsthetised cases, the size was not influenced by anoxia, even when this was severe.

In rabbits, anæsthetised and not anæsthetised, pro- longed and severe respiratory distress did not result in pupillary dilatation. On the contrary, pupils contracted during the last 30 seconds before death. Circulatory arrest was followed by an immediate increase of pupillary diameter, independent of whether the animal was anæesthetised or not.

These clinical observations and experimental data do not support the common concept that anoxia causes a dilatation of the pupils. Estimation of pupillary size should be omitted from a simple clinical evaluation of anoxia.

The findings do not support the suggestion (Macintosh and Bannister 1945) that pupillary dilatation during anæsthesia overdosage is due to anoxia. In our series, neither anoxæmia nor brain-tissue anoxia seem to have caused dilatation, judging from those cases with a very low $\mathrm{P}_{\mathrm{a}} \mathrm{O}_{2}$ where the brain tissue must have suffered hypoxia. Pupillary enlargement seen during dying more or less coincides with, but need not be due to, cessation of cerebral circulation. Clearly, explanations of pupillary signs in respiratory diseases need revision.

REFERENCES

Allen, C. R., Echols, R. S., Hoeflich, E. A., O'Neal, K. C., Slocum, H. C. (1947) Anesthesiology, 8, 601.

Clement, F. W. (1951) Nitrous Oxide-Oxygen Anæsthesia. Philadelphia.

Kopp, J., Poulsen, G. (1966) Neurology, 16, 225

Macintosh, R. R., Bannister, F. B. (1945) Essentials of General Anæsthesia Oxford.

\section{IN-VIVO AND IN-VITRO EFFECTS OF POLYVINYLPYRROLIDONE ON}

\section{PLATELET ADHESIVENESS IN HUMAN BLOOD}

SHAFEEK S. SANBAR

M.D., B.Sc. Beirut, Ph.D. Norman

ASSISTANT PROFESSOR OF INTERNAL MEDICINE

ANDREW J. ZWEIFLER

M.D. Philadelphia

ASSOCIATE PROFESSOR OF INTERNAL MEDICINE

GUIDO SMET

M.D. Louvain

RESEARCH ASSISTANT, HYPERTENSION UNIT

From the Department of Internal Medicine, University of Michigan, Ann Arbor

Summary Intravenous infusion of $500 \mathrm{ml}$. $6 \%$ polyvinylpyrrolidone (P.V.P. (Mw 40,000) in isotonic saline solution over a 2 -hour period significantly diminished platelet adhesiveness in eight subjects from $27 \%$ before infusion to as low as $10 \%$ at the end of the infusion. 5 hours after the end of the infusion, platelet adhesiveness was still significantly reduced $(16 \%)$. The addition of P.V.P. to citrated blood in vitro significantly decreased platelet adhesiveness. Both in vivo and in vitro, the platelet-count was not significantly altered by P.V.P. The in-vivo change in platelet adhesiveness is similar to that reported by others with dextran-a plasma expander that differs chemically from P.V.P.

\section{Introduction}

PolyvinylPYRRolidone (P.V.P.) is a plasma-volume expander (Gropper et al. 1952) which was developed during the early part of the 1939-45 war by Hecht and Weese (1943). Its hæmodynamic effects, which result in part from plasma expansion, have been well documented (De Freitas et al. 1965). Of particular interest, however, 
are the varied properties of P.V.P. which seemingly are not related to plasma-volume expansion. P.V.P. can chemically bind dyes, bilirubin, insulin, penicillin, and other drugs (Gropper et al. 1952). Intravenous infusion of P.V.P. strikingly diminishes serum-lipid concentrations in the nephrotic syndrome (Allen et al. 1961) and in familial hyperlipoproteinæmia (Sanbar et al. 1967). P.V.P. infusion has been shown to increase the aggregation of erythrocytes (Korth and Heinlein 1943) and their sedimentation-rate (Guillot and Fiehrer 1948) but does not lengthen the bleeding-time or clotting-time (Thrower and Campbell 1951). Finally, high concentrations of P.V.P. (about $40 \%$ ) have been shown to protect human erythrocytes effectively during frozen storage in liquid nitrogen (Richards et al. 1964). At these concentrations, P.V.P. precipitates some plasma-proteins (Burstein 1961) such as almost all of the plasma-fibrinogen and antihæmophilic factor VIII and variable amounts of other coagulation factors (Perkins et al. 1966)

We report here another effect of P.V.P.-namely, that it can diminish platelet adhesiveness in human blood both in vivo and in vitro. Our investigation was prompted by reports that dextran, a chemically different plasma expander, decreases platelet adhesiveness in man (Bennett et al. 1966, Bygdeman et al. 1966, Cronberg et al. 1966).

\section{Subjects and Methods}

In-vivo infusions were carried out on two men and six women who had fasted for 12-16 hours. They were all clinically well at the time, but they had essential hypercholesterolæmia. After a baseline blood-sample was obtained, each was given a 2-hour intravenous infusion of $500 \mathrm{ml} .6 \%$ P.V.P. in isotonic saline solution. Blood-samples were then taken at the end of the infusion, and at 4 and 7 hours after the start of the infusion.

In-vitro tests.-Blood-samples, $20 \mathrm{ml}$. each, were obtained from thirteen healthy volunteers and transferred to plastic beakers. Portions were then drawn into individual $5 \mathrm{ml}$. siliconised syringes as follows:

(1) $5.0 \mathrm{ml}$. blood was used as such with nothing added

(2) $4.5 \mathrm{ml}$. blood, plus $0.5 \mathrm{ml}$. isotonic saline solution.

(3) $4.5 \mathrm{ml}$. blood, plus $0.5 \mathrm{ml} .6 \%$ P.V.P. in isotonic saline solution.

(4) $4.5 \mathrm{ml}$. blood, plus $0.5 \mathrm{ml}$. isotonic saline solution.

The amount of P.V.P. selected was comparable to the amount administered intravenously. Blood was kept at room-temperature while platelet adhesiveness was being measured successively in the order indicated.

Technique.-All blood-samples were initially collected in siliconised glass syringes containing $3.8 \%$ sodium citrate (1 part citrate to 9 parts blood). Platelet adhesiveness to glass beads was measured according to the technique of Hellem (1960); the platelets were counted according to the method of Brecher and Cronkite (1950).

\section{Results}

Intravenous infusion of $500 \mathrm{ml} .6 \%$ P.V.P. over a 2-hour period decreased platelet adhesiveness in six of the eight subjects (table I). In the two unaffected subjects, the percentage of platelet adhesiveness was remarkably low before the infusion. The mean percentage of platelet adhesiveness was lowest at the end of the infusion and was still significantly reduced 5 hours later. Mean ( \pm S.E.M.) platelet-counts did not change significantly throughout the procedure $-261,000$ ( $\pm 28,000)$ before infusion, 234,500 $( \pm 23,900)$ at 2 hours, $242,000( \pm 25,500)$ at 4 hours, and $230,800( \pm 18,600)$ at 7 hours after the infusion was begun.

Table II shows that addition of $0.5 \mathrm{ml}$. isotonic saline solution to $4.5 \mathrm{ml}$. blood (columns 3 and 5 ) had no influence
TABLE I-IN-VIVO INFUSION OF 500 ML. $6 \%$ P.V.P.

\begin{tabular}{c|c|c|c|c}
\hline \multirow{2}{*}{$\begin{array}{c}\text { Subject } \\
\text { no. }\end{array}$} & \multicolumn{4}{|c}{ Platelet adhesiveness (\%) } \\
\cline { 2 - 5 } & $\begin{array}{c}\text { Before } \\
\text { infusion }\end{array}$ & \multicolumn{2}{|c}{ Hours after start of P.v.P. infusion } \\
\cline { 2 - 4 } & 2 & 2 & 4 & 7 \\
\hline 1 & 34 & 3 & 1 & 21 \\
2 & 23 & 1 & 8 & 10 \\
3 & 29 & 24 & 22 & 20 \\
4 & 38 & 9 & 13 & 19 \\
5 & 34 & 13 & 10 & 10 \\
6 & 17 & 15 & 20 &. \\
7 & 11 & 12 & 14 & 13 \\
8 & 29 & 4 & 15 & $16 \pm 2$ \\
\hline Mean \pm S.E.M. & $27 \pm 3$ & $10 \pm 3$ & $13 \pm 2$ & \\
\hline
\end{tabular}

TABLE II-IN-VITRO EFFECT OF P.V.P. ON PLATELET ADHESIVENES

\begin{tabular}{|c|c|c|c|c|}
\hline \multirow{3}{*}{$\begin{array}{c}\text { Sample } \\
\text { no. }\end{array}$} & \multicolumn{4}{|c|}{ Platelet adhesiveness $(\%)$} \\
\hline & \multirow{2}{*}{$\begin{array}{l}5.0 \mathrm{ml} \\
\text { citrated } \\
\text { blood }\end{array}$} & \multicolumn{3}{|c|}{$4.5 \mathrm{ml}$. of citrated blood } \\
\hline & & $\begin{array}{l}+0.5 \mathrm{ml} \\
\text { saline } \\
\text { solution }\end{array}$ & $\begin{array}{c}+0.5 \mathrm{ml} . \\
6 \% \text { P.V.P. } \\
\text { solution }\end{array}$ & $\begin{array}{c}+0.5 \mathrm{ml} . \\
\text { saline } \\
\text { solution }\end{array}$ \\
\hline 1 & 20 & 18 & 8 & 18 \\
\hline 2 & 33 & 25 & 18 & 33 \\
\hline 3 & 25 & 25 & 20 & 22 \\
\hline 4 & 37 & 23 & 31 & 28 \\
\hline 5 & 27 & 28 & 15 & 27 \\
\hline 6 & 19 & 14 & 0 & 26 \\
\hline 7 & 24 & 44 & 8 & 38 \\
\hline 8 & 37 & 17 & 16 & 17 \\
\hline 9 & 25 & 42 & 27 & 44 \\
\hline 10 & 31 & 37 & 30 & 37 \\
\hline 11 & 46 & 22 & 22 & 26 \\
\hline 12 & 8 & 29 & 13 & 16 \\
\hline 13 & 13 & 16 & 29 & 10 \\
\hline Mean \pm S.E.M. & $26 \pm 3$ & $26 \pm 3$ & $18 \pm 3$ & $26 \pm 3$ \\
\hline
\end{tabular}

on platelet adhesiveness of citrated whole blood (column 2), On the other hand, the addition of $0.5 \mathrm{ml} .6 \%$ P.V.P. in isotonic saline solution (column 4) decreased platelet adhesiveness impressively. Mean ( \pm S.E.M.) plateletcounts were not significantly different in the four subgroups-192,400 ( $\pm 12,600), 181,100( \pm 14,300), 165,700$ $( \pm 12,300)$, and $175,500( \pm 12,300)$ beginning with citrated blood only, then with saline solution, P.V.P., and finally saline solution again.

Discussion

Our findings show that P.V.P. can substantially reduce platelet adhesiveness in human blood both in vivo and in vitro. This effect has not been previously reported, though the chemically different plasma expander, dextran, has been shown to influence platelet adhesiveness (Bygdeman et al. 1966, Bennett et al. 1966). The effects of these two plasma expanders on platelet adhesiveness, however, are somewhat different. P.V.P. decreases platelet adhesiveness both in vivo and in vitro, whereas dextran has not been shown to produce this effect in vitro (Bygdeman and Eliasson 1966). P.V.P. exerts its maximum effect on platelet adhesiveness at the end of the infusion of the drug, whereas the maximum effect of dextran on platelet adhesiveness does not coincide with its peak concentration in the blood but is delayed for several hours (Bennett et al. 1966, Cronberg et al. 1966).

How P.v.P. reduces platelet adhesiveness is not clear from our investigation. The reduction is apparently not secondary to changes in platelet-counts. Nor is it likely to be related to changes in red-cell concentration (Hellem 1960), since the reduction in adhesiveness after P.V.P. infusion is greater than would be expected from changes 
in hæmatocrit (Salzman and Neri 1966) and (more importantly), because we found that dilution with equal volumes of saline solution alone " in vitro" had no effect at all. In view of the decrease in platelet adhesiveness by P.V.P. both in vivo and in vitro, the most plausible explanation is that P.V.P. " coats" the blood-platelets, foreign surfaces, or erythrocytes, thereby preventing adhesion of platelets to the foreign surface as well as trauma to the erythrocytes and the consequent release of adenosine diphosphate. Nevertheless, regardless of the exact way in which P.V.P. decreases platelet adhesiveness, the clinical potential of such an agent in the prevention of thrombus formation or propagation is important. And, as in the case of dextran (Bennett et al. 1966), the prophylactic and therapeutic value of the possible antithrombotic properties of P.V.P. should be fully investigated.

We are grateful to all who took part in this investigation, including the nurses of the clinical research unit, University Hospital, Ann Arbor; and to Mrs. A. Harper, Mrs. S. Jackson, and Mr. C. Reynolds. This work was supported in part by grants from the National Institutes of Health, 5MO1-FR-42-07, and the Michigan Heart Association, and was completed during tenure by S. S. S. of an advanced research fellowship of the American Heart Association.

Requests for reprints should be addressed to S. S. S., department of internal medicine, University of Michigan, Ann Arbor, Michigan 48104, U.S.A.

\section{REFERENCES}

Allen, J. C., Baxter, J. H., Goodman, H. C. (1961) f. clin. Invest. 40, 499.

Bennett, P. N., Dhall, D. P., McKenzie, F. N., Matheson, N. A. (1966) Lancet, ii, 1001

Brecher, G., Cronkite, E. P. (1950) F. appl. Physiol. 3, 365.

Burstein, M. J. (1961) F. Physiol., Paris, 53, 519.

Bygdeman, S., Eliasson, R. (1966) Thromb. Diath. heemorrh. 15, 436.

- - Gullbring, B. (1966) ibid. p. 451.

Cronberg, S., Robertson, B., Nilsson, I. M., Niléhn, J.-E. (1966) ibid. 12, 384.

De Freitas, F. M., Faraco, E. Z., De Azevedo, D. F., Zaduchliver, J., Lewin, I. (1965) F. clin. Invest. 44, 3.

Gropper, A. L., Raisz, L. G., Amspacher, W. H. (1952) Int. Abstr. Surg. 95, 521.

Guillot, M., Fiehrer, A. (1948) Sang. 19, 59

Hecht, G., Weese, H. (1943) Munch. med. Wschr. 90, 11.

Hellem, A. J. (1960) Scand. F. clin. Lab. Invest. 12, Suppl. 5, 1

Korth, J., Heinlein, H. (1943) Arch. klin. Chir. 259, 242.

Perkins, H. A., Rolfs, M. R., Thacher, C., Richards, V. (1966) Proc. Soc. exp. Biol. Med. 123, 667.

Richards, V., Braverman, M., Floridia, R., Persidsky, M., Lowenstein, J. (1964) Am. F. Surg. 108, 313.

Sanbar, S. S., Smet, G., Zweifler, A. J. (1967) Circulation 36, 36

Salzman, E. W., Neri, L. L. (1966) Thromb. Diath. hamorrh. 15, 84.

Thrower, W. R., Campbell, H. (1951) Lancet, i, 1096.

\section{TWO CASES OF HEPATITIS DUE TO TOXOPLASMA GONDII}

\author{
T. L. VISCHER \\ M.D. Basel \\ C. BERNhEIM \\ M.D. Zürich
}

OF THE MEDICAL POLYCLINIC, UNIVERSITY OF GENEVA

\section{E. ENGELBRECHT}

M.D. Leyden

OF THE MICROBIOLOGY SERVICE, INSTITUTE OF HYGIENE, GENEVA

Summary

Two cases of hepatitis clinically and biologically resembling acute viral hepatitis are reported. In both, Toxoplasma gondii could be demonstrated in the liver, together with a significant, rise in antitoxoplasmic antibodies. The two cases had prolonged prodromal stages with lymphadenopathy, anorexia, and fatigue before the onset of jaundice. It could be that more cases of so-called viral hepatitis are caused by T. gondii.

\section{Introduction}

SEROLOGICAL evidence indicates that about $20 \%$ of the adult population have been infected at one time or another with Toxoplasma gondii (Buhler 1963, Hurwitz 1965). Infection after infancy usually passes unrecognised. Sometimes it may cause chorioretinitis or lymphadenopathy; "glandular fever" unaccompanied by a PaulBunnel reaction can be due to toxoplasmosis. Rare manifestations are encephalitis, a severe and often fatal typhus-like disease, and myocarditis (The Lancet 1959). Liver involvement has been reported in patients with generalised disease due to toxoplasma (Theologides and Kennedy 1966). A chronic kind of hepatitis due to toxoplasmosis with slight elevation of serum-bilirubin has been reported by Kabelitz (1959) who based his conclusions on serological evidence. We describe here two cases of acute hepatitis--in both, $T$. gondii was demonstrated in the liver.

\section{Methods}

Serological tests for toxoplasmosis were done with four different techniques: the dye test (Sabin and Feldman 1948), the indirect hæmagglutination reaction (I.H.R.; Jacobs and Lunde 1957), the slide flocculation test (Engelbrecht 1965), and a complement-fixation (C.F.) test using 1.5 units of complement and the formalised insoluble residue of repeatedly frozen and thawed, water-extracted toxoplasma as an antigen. $T$. gondii was demonstrated in liver-biopsy specimens by immunofluorescence: the tissues were fixed in acetone for 24 hours, passed through benzene, and imbedded in paraffin wax at $50-55^{\circ} \mathrm{C}$. Sections were cut and, after paraffin wax had been removed in benzene for 10 minutes, they were rinsed once in acetone. Control slides of toxoplasmic mouse exudate were treated in the same way. Of two successive sections and two control slides one was treated with a known normal human serum while the other one was treated with a human serum of high dye-test titre (inhibitory serum), both sera being diluted to $1 / 5$ with phosphate-buffered saline solution $\mathrm{pH} 7,2$. Slides were incubated for 40 minutes at $37^{\circ} \mathrm{C}$ and then rinsed with the buffered saline solution. Subsequently, they were incubated with a dilution of human serum which had a high dye-test titre, conjugated with fluorescein isothiocyanate. After washing several times in phosphate-buffered saline solution, the sections were examined under the ultraviolet microscope. Of the control slides, the one which was pretreated with normal serum showed brilliant staining of the toxoplasma; the control slide with inhibitory serum only showed faint fluorescence. The first of the liver sections showed fluorescent particles morphologically indistinguishable from $T$. gondii, while on the other section the particles were seen at the same sites with only faint staining.

\section{Case-reports \\ FIRST CASE}

A 61-year-old housewife was admitted with jaundice on Dec. $6,1966.3$ months before admission, she had had an acute febrile episode of 1 week's duration, followed by asthenia, fatigue, and subfebrile temperatures. Clinical examination 2 months before admission revealed two pea-sized mobile anterior neck lymph-nodes. I.H.R. for toxoplasmosis showed a titre of $1 / 160.1$ month's treatment with sulphadimethoxine and spiramycin had no effect. On Dec. 2, after a few days of nausea, mild pruritus, dark urine, and light-coloured stools, slight jaundice developed, and the patient was referred to hospital. Past history revealed nothing relevant except hiatal hernia. Blood had been taken several times during the 3 preceding months; otherwise there was no history of exposure to hepatitis, hepatotoxic agents, or domestic pets. Physical examination showed a moderately obese icteric woman who had lately lost $4 \mathrm{~kg}$. (8.8 lb.) of weight; liver tender and palpable $8 \mathrm{~cm}$. below costal margin; a soft spleen $3 \mathrm{~cm}$. below left costal margin. Laboratory data are shown in the table. Peripheral white-blood-cell count was 7200 with $27 \%$ polymorphnuclear cells, $12.5 \%$ band forms, $0.5 \%$ eosinophils, $0.5 \%$ basophils, $14.5 \%$ monocytes, $43.5 \%$ lymphocytes with viral cytoplasm, and $1.5 \%$ plasmocytes. The increase in mononuclear cells persisted throughout the course of the disease. C.F. tests for 